\title{
What is the extent of research on the characteristics, behaviors, and impacts of health information technology champions? A scoping review
}

\author{
Christopher Michael Shea ${ }^{*}$ and Charles M. Belden
}

\begin{abstract}
Background: Although champions are commonly employed in health information technology (HIT) implementations, the state of empirical literature on HIT champions' is unclear. The purpose of our review was to synthesize quantitative and qualitative studies to identify the extent of research on the characteristics, behaviors, and impacts of HIT champions. Ultimately, our goal was to identify gaps in the literature and inform implementation science.

Methods: Our review employed a broad search strategy using multiple databases-Embase, Pubmed, Cinahl, Psychlnfo, Web of Science, and the Cochrane library. We identified 1728 candidate articles, of which 42 were retained for full-text review.

Results: Of the 42 studies included, fourteen studies employed a multiple-case study design (33\%), 12 additional articles employed a single-case study design (29\%), five used quantitative methods (12\%), two used mixed-methods (5\%), and one used a Delphi methodology (2\%). Our review revealed multiple categories and characteristics of champions as well as influence tactics they used to promote an HIT project. Furthermore, studies have assessed three general types of HIT champion impacts: (1) impacts on the implementation process of a specific HIT; (2) impacts on usage behavior or overall success of a specific HIT; and (3) impacts on general organizational-level innovativeness. However the extent to which HIT projects fail even with a champion and why such failures occur is not clear. Also unclear is whether all organizations require a champion for successful HIT project implementation. In other words, we currently do not know enough about the conditions under which (1) a health IT champion is needed, (2) multiple champions are needed, and (3) an appointed champion - as opposed to an emergent champion — can be successful. Conclusions: Although champions appear to have contributed to successful implementation of HIT projects, simply measuring the presence or absence of a champion is not sufficient for assessing impacts. Future research should aim for answers to questions about who champions should be, when they should be engaged, what they should do, how management can support their efforts, and what their impact is given the organizational context.
\end{abstract}

Keywords: Health information technology, Champion, Implementation science, Organizational innovation, Organizational change

\footnotetext{
* Correspondence: chris_shea@unc.edu

CB\# 7411 McGavran-Greenberg Hall, Gillings School of Global Public Health,

University of North Carolina-Chapel Hill, Chapel Hill, NC 27599-7411, USA
} 


\section{Background}

The promise of increased health information access and information exchange for improving health systems and patient outcomes has prompted efforts within many countries to enhance the health information technology (HIT) infrastructure. For example, in the United States, financial incentives through the Medicare and Medicaid programs for "Meaningful Use" of electronic health records (EHR) are contributing to substantial increases in adoption of EHRs and related HIT. Between 2009 and 2012, physician adoption of EHR technology used to demonstrate five Meaningful Use core objectives increased by approximately $66 \%$ [1], and by the end of 2012, more than $75 \%$ of all eligible U.S. hospitals had qualified for financial incentives [2]. As of July 2015, eligible hospitals and providers had received more than $\$ 31 \mathrm{~B}$ in Meaningful Use incentive payments [3]. In addition to Meaningful Use, value-based payment and care delivery models in the U.S., such as Accountable Care Organizations, are increasing the need for health care providers and organizations to exchange patient information electronically [4], thus incentivizing the adoption of interoperable EHR systems.

Although adoption of EHRs and other HIT is increasing, implementation of these innovations carries substantial risk due to the financial investment required, the potential to negatively affect the provider and patient experience, and the opportunity cost of failure. Furthermore, implementing new health information systems is complex because these systems affect multiple organizational members and work processes [5]. Because of the risk and complexity involved, organizations are typically advised to undergo a careful planning process and dedicate adequate financial and human resources in order to deploy successful implementation strategies $[6,7]$.

Numerous approaches for implementing HIT and similar innovations in health care organizations have been documented, but there is mixed evidence about which are most important for promoting consistent and appropriate use of these innovations [7, 8]. Having a champion to promote an innovation and support the requisite change effort (i.e., "fight for the cause") is one approach commonly cited in the literature and used in practice $[9,10]$. Despite being commonly employed in HIT implementations, however, champions may not be well understood. For example, several years ago Howell and Higgins, whose work was not health specific, identified that research has not sufficiently examined the characteristics of champions or how their roles may (or may not) differ from other organizational members in the implementation process $[11,12]$. Now, approximately 25 years after Howell and Higgins made these observations, the current state of the literature on HIT champions, in particular, is unclear. This lack of clarity impedes development of evidence-based approaches for identifying champions, supporting the efforts of champions, and assessing the impacts of champions. The purpose of our review was to synthesize empirical studies, both quantitative and qualitative, to identify the extent of research on the characteristics, behaviors, and impacts of HIT champions. Ultimately, our goal was to identify gaps in the literature on HIT champions to inform future research.

\section{Methods}

We conducted a scoping review, which "provides a preliminary assessment of the size and scope of available research literature" [13]. Scoping reviews are similar to systematic reviews with respect to search methodology and approach to describing a body of literature. However, systematic reviews typically have more specific research questions than do scoping reviews. Also, systematic reviews use methodologies to assess the quality of articles included in the review, whereas scoping reviews typically do not [14]. We chose to conduct a scoping review because we anticipated that HIT champions had not been well studied and that there would not be a sufficient evidence base to answer specific research questions about HIT champion impacts. The methods we employed were similar to those recommended for scoping studies by Levac et al., for example (1) combining a broad research question with a clearly articulated scope and clear definitions of key concepts; (2) using an iterative, team-oriented approach to study selection and data abstraction; and (3) drawing upon qualitative analytical techniques to identify themes in the literature [15].

\section{Data sources and searches}

We conducted searches for relevant studies in Embase, Pubmed, Cinahl, PsychInfo, Web of Science, and the Cochrane library through September 2014. Prior to submitting the manuscript for review, we conducted an additional search to determine whether additional relevant articles had been published since our original search. For our review, we defined champion as an individual who is a member of an organization (i.e., internal) and facilitates the change necessary to implement a new HIT system within the organization. This definition is consistent with Schon's seminal definition of product champion [16]. Although champion is distinct from concepts such as change agent and opinion leader [17], we anticipated that some authors might use such terms synonymously. Therefore, we used a broad range of search terms: champion, change agent, innovator, opinion leader, super user, entrepreneur, leader, and boundary spanner. In addition to our database searches, we manually forward-searched references of articles that met our inclusion criteria to identify additional articles that might 
be relevant but did not appear in our database search results.

\section{Study selection}

Because we were particularly interested in champions of HIT implementation, we included only articles about such champions, rather than using the broader strategy of including champions of any type of organizational change (e.g., an educational intervention) or champions of IT in all types of settings (e.g., manufacturing companies). We did so because implementing IT, unlike some other types of innovations, requires learning to use a new technology and modifying existing work processes; therefore, IT implementation may require different champion characteristics and tactics as compared to other innovations. Also, health care organizations are organized and staffed in ways that are substantially different from most other types of organizations and provide services to clients (patients) that are not analogous to other types of products/services. In summary, studies of changes unrelated to IT in healthcare settings, or of IT implementations in non-health settings, likely would yield some results not applicable to champions of HIT.

Studies were excluded from full-text review if they did not meet the following criteria:

1. Written in English

2. Published in 1990 or later

3. Abstract available

4. Empirical study using qualitative or quantitative methods

5. Investigates development, implementation, and/or use of health information technology. HITECH Act definition of health information technology:

"hardware, software, integrated technologies, or related licenses, intellectual property, upgrades, or packaged solutions sold as services that are designed for or support the use by health care entities or patients for the electronic creation, maintenance, access, or exchange of health information" [18]. Examples include technologies involving clinical notes, medication lists, radiology and laboratory results, alerts, and telemedicine.

6. Includes analysis of a champion that is internal to the organization implementing the HIT.

This study used the PRISMA statement flow chart to analyze literature search results (Fig. 1). After one author (CB) reviewed abstracts using the inclusion criterion 1 through 4 (listed above), a $20 \%$ random sample of the abstracts was selected and reviewed by the other author (CS) to validate the inclusion/exclusion process. Using inclusion criteria $1-6$, both authors (CB and CS) then completed a full-text review of articles that were not excluded during abstract review.

\section{Data extraction}

Articles selected for full-text review were charted $[15,19]$ using a charting form developed in an Excel spreadsheet $[19,20]$. We adapted the Howell \& Higgins framework [11] to determine which variables were needed to answer the research questions. We then iteratively developed the charting form used to extract the variables from each study. One member of the research team (CB) extracted data from all articles included in the review, and the other team member (CS) performed the same process on a sample of articles [15]. The charting form included the following fields for each study:

- Author, year, setting, study design, sample

- Type of HIT studied

- Whether the term "champion" was used. If so, whether "champion" was explicitly defined; if not, which term was used instead of champion.

- Champion characteristics (e.g., role in the organization)

- Champion influence tactics (e.g., building coalitions)

- Management support for the champion (e.g., supporting pilot projects)

- Champion impact (e.g., on adoption)

Once the charting process was complete, we synthesized the results to develop summary findings pertinent to the variables in the charting form. Consistent with the stated purpose of our review, we then considered these summary findings in the context of current HIT implementation practice in order to develop recommendations for future research [15].

\section{Results}

\section{Study selection}

Our database search identified 1902 articles, and we identified three additional articles from forward searches on Howell and Higgins [11]. After removing duplicates, we were left with 1728 candidate articles. We were unable to locate three of these papers [21-23]. After title review, we excluded 1642 of the articles. Agreement on exclusion of studies at this stage was $99 \%$ in the $20 \%$ random sample $(n=344)$ reviewed by both authors. After abstract review, 48 articles remained for full-text review, during which 6 additional articles were excluded.

\section{Study characteristics}

Table 1 summarizes the settings, methods, and main findings of the articles included in our review. Of the 42 articles included in our full-text review, 34 (81\%) used the term champion, and 8 (19\%) provided an explicit 


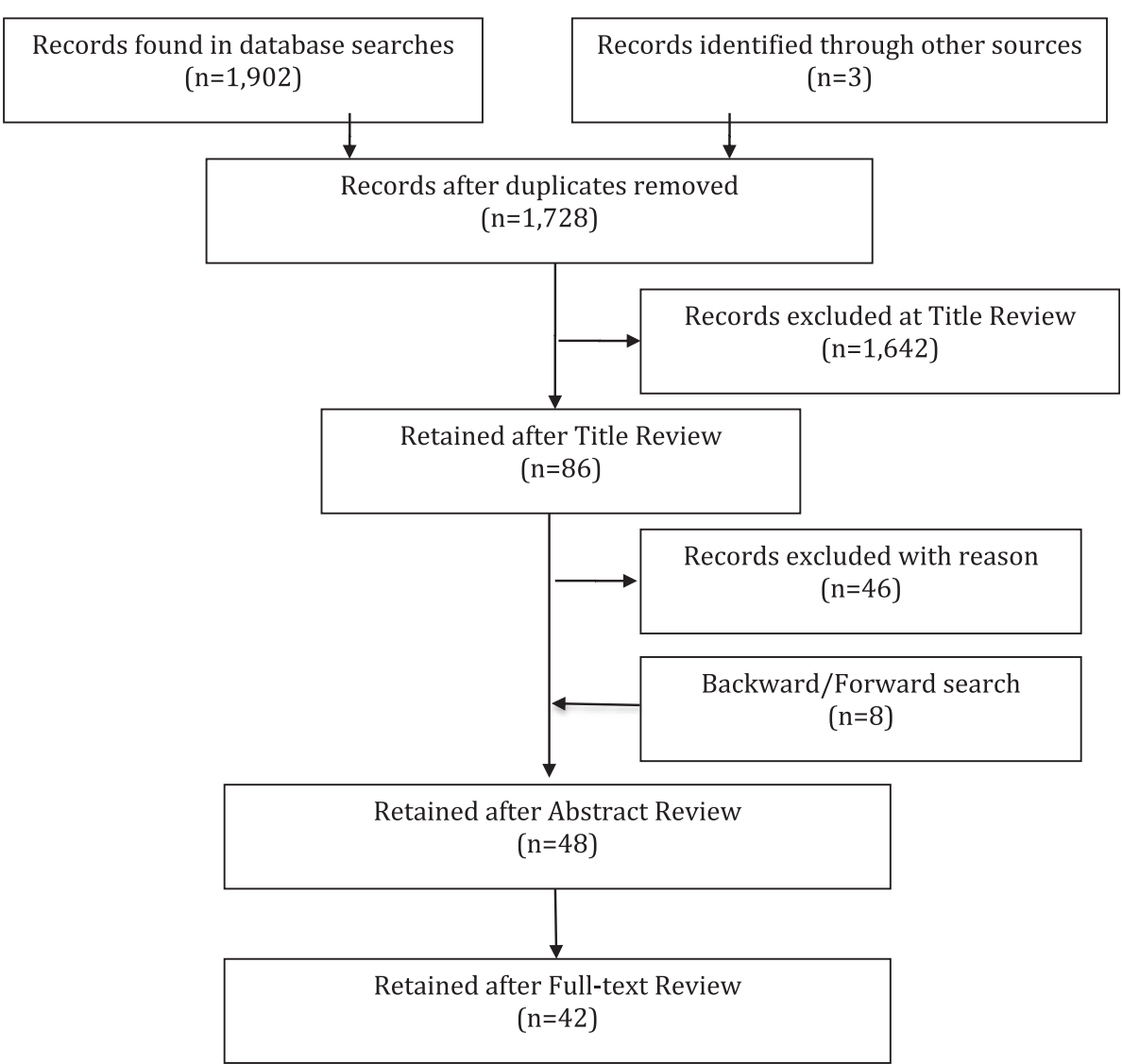

Fig. 1 PRISMA diagram for the HIT champion literature search

definition of the term champion. Articles that did not use the term champion used terms such as change agent [24], bilingual coach [25], opinion leader [26, 27], innovator [28], facilitator [29], and super user [30]. Despite the variation in terms used, we were able to ascertain that each of the 42 studies included in our review described an HIT champion as we defined the concept, i.e., an individual who is a member of an organization (i.e., internal) implementing a new HIT system within the organization. Fourteen studies employed a multiplecase study design (33\%), 12 additional articles employed a single-case study design ( $29 \%$ ), five used quantitative methods (12\%), two used mixed-methods (5\%), and one used a Delphi methodology (2\%). Below we synthesize the characteristics, behaviors, and impacts of IT champions from studies included in our review. Table 2 summarizes this information for each study.

\section{Champion characteristics Personality characteristics}

We identified 20 articles representing 19 studies that described characteristics of champions similar to those identified by Howell and Higgins [11], including achievement [31-40]; persuasiveness [36-39, 41-44]; persistence
[10, 43, 45, 46]; innovativeness [31, 35, 36, 38-40, 43, 46-48]; charisma [36, 39, 47]; enthusiasm [35-37, 39, 40]; assertiveness [28, 36, 39, 47]; risk-tolerance [28, 38, 46]. Furthermore, many of the champions in our review demonstrated combinations of the personality characteristics mentioned above, such as achievement and innovativeness [28, 32, 33, 35, 39, 40]; persistence and persuasiveness [29, 41, 43, 44]; achievement, innovativeness, and persuasiveness [31, 38, 39]; and achievement, innovativeness, persistence, and persuasiveness [31, 36, 39].

\section{Organizational role}

Champions held formal leadership roles such as medical director, nurse manager, chief information officer, chief medical information officer, practice manager, or office manager [24, 28, 31-33, 39, 41, 43, 47, 49-53]. However, there were also cases where champions did not have a formal leadership role in the organization [25$28,30-34,39,43,44,46-48,50-52,54-56]$. Some champions held dual roles with administrative and clinical responsibilities $[24,32,33,38-41,51]$, or clinical and technical responsibilities [36, 46]. Furthermore, in some studies champions were described as emergent $[26,30,32,33,38,39,52]$, whereas in other studies 
Table 1 Summary of articles included in the review of HIT champions $(n=42)$

\begin{tabular}{|c|c|c|c|c|}
\hline Reference & Intervention & Setting & $\begin{array}{l}\text { Evaluative } \\
\text { method }\end{array}$ & Objectives \\
\hline Al-Qirim [32] & Telehealth & $\begin{array}{l}\text { One Dermatology Department in } \\
\text { New Zealand. }\end{array}$ & Case study & $\begin{array}{l}\text { Explain factors influencing the adoptio } \\
\text { and diffusion of telemedicine for } \\
\text { dermatology. }\end{array}$ \\
\hline Al-Qirim [33] & Telehealth & $\begin{array}{l}\text { One Psychiatry Department, and one } \\
\text { Dermatology Department in New } \\
\text { Zealand. }\end{array}$ & Case study & $\begin{array}{l}\text { Explain factors influencing the adoptio } \\
\text { and diffusion of telemedicine for } \\
\text { psychiatry and dermatology. }\end{array}$ \\
\hline $\begin{array}{l}\text { Andre, Ringdal, Loge, } \\
\text { Rannestad, Kaasa [63] }\end{array}$ & $\begin{array}{l}\text { Handheld symptom } \\
\text { assessment }\end{array}$ & $\begin{array}{l}\text { Oncology Department in University } \\
\text { Hospital (Norway) }\end{array}$ & Case study & $\begin{array}{l}\text { Examine responses and attitudes of } \\
\text { users, and factors promoting } \\
\text { implementation. }\end{array}$ \\
\hline $\begin{array}{l}\text { Ash, Stavri, Dykstra, } \\
\text { Fournier [31] }\end{array}$ & $\begin{array}{l}\text { Computerized physician } \\
\text { order entry (CPOE) }\end{array}$ & $\begin{array}{l}\text { One Teaching hospital in Virginia (USA), } \\
\text { Veteran's health care system in } \\
\text { Washington (USA), one non-profit } \\
\text { hospital in California (USA) }\end{array}$ & $\begin{array}{l}\text { Multiple case } \\
\text { study }\end{array}$ & $\begin{array}{l}\text { Identify factors associated with the } \\
\text { implementation of CPOE in inpatient } \\
\text { and outpatient settings. }\end{array}$ \\
\hline $\begin{array}{l}\text { Ash, Gorman, Lavelle, } \\
\text { Payne, Massaro, Frnatz, } \\
\text { Lyman [34] }\end{array}$ & $\begin{array}{l}\text { Computerized physician } \\
\text { order entry (CPOE) }\end{array}$ & $\begin{array}{l}\text { University of Virginia (USA), Veterans } \\
\text { Affairs Puget Sound Health Care } \\
\text { System (USA), El Camino Hospital (USA) }\end{array}$ & $\begin{array}{l}\text { Observation, } \\
\text { interviews, } \\
\text { and focus } \\
\text { groups }\end{array}$ & $\begin{array}{l}\text { Describe perceptions of CPOE among } \\
\text { diverse professionals in sites with } \\
\text { successful CPOE implementation }\end{array}$ \\
\hline Ash, Sittig, Wright [57] & $\begin{array}{l}\text { Clinical decision support } \\
\text { (CDS) }\end{array}$ & $\begin{array}{l}\text { Independent physician organization in } \\
\text { Oregon (USA). }\end{array}$ & Case study & $\begin{array}{l}\text { Identify barriers and facilitators of CDS } \\
\text { implementation in a community } \\
\text { setting. }\end{array}$ \\
\hline $\begin{array}{l}\text { Ash, Sittig, Guappone, } \\
\text { Dykstra, Richardson, } \\
\text { Wright, Carpenter, } \\
\text { McMullen, Shapiro, } \\
\text { Bunce, Middleton [47] }\end{array}$ & $\begin{array}{l}\text { Clinical decision support } \\
\text { (CDS) }\end{array}$ & $\begin{array}{l}\text { Two community hospitals and five } \\
\text { ambulatory clinics in the US. }\end{array}$ & $\begin{array}{l}\text { Multiple case } \\
\text { study }\end{array}$ & $\begin{array}{l}\text { Identify factors associated with } \\
\text { implementation of CDS. }\end{array}$ \\
\hline $\begin{array}{l}\text { Carlfjord, Lindberg, } \\
\text { Andersson [35] }\end{array}$ & $\begin{array}{l}\text { Computer-based lifestyle } \\
\text { intervention. }\end{array}$ & $\begin{array}{l}\text { Six primary health care }(\mathrm{PHC}) \text { centres } \\
\text { in Sweden. }\end{array}$ & $\begin{array}{l}\text { Multiple case } \\
\text { study }\end{array}$ & $\begin{array}{l}\text { Explore organizational members' } \\
\text { perceptions and usefulness of a } \\
\text { computer-based lifestyle intervention. }\end{array}$ \\
\hline $\begin{array}{l}\text { Chedid, Golden, } \\
\text { Jager [56] }\end{array}$ & $\begin{array}{l}\text { University of Chicago } \\
\text { Medicine's Diabetic } \\
\text { Retinopathy Screening } \\
\text { Program }\end{array}$ & $\begin{array}{l}\text { Chicago Family Health Center } \\
\text { (Federally qualified health center). }\end{array}$ & Case study & $\begin{array}{l}\text { Identify operational challenges in the } \\
\text { implementation of a diabetic } \\
\text { retinopathy screening program. }\end{array}$ \\
\hline $\begin{array}{l}\text { Cresswell, Sadler, } \\
\text { Rodgers, Avery, Cantrill, } \\
\text { Murray, Sheikh [24] }\end{array}$ & $\begin{array}{l}\text { Pharmacist-led information } \\
\text { technology intervention. }\end{array}$ & $\begin{array}{l}34 \text { primary care organizations in } \\
\text { central England (UK). }\end{array}$ & Case Study & $\begin{array}{l}\text { Understand the organizational and } \\
\text { social environment of a pharmacist- } \\
\text { led information technology } \\
\text { intervention. }\end{array}$ \\
\hline $\begin{array}{l}\text { Crosson, Etz, Wu, Straus, } \\
\text { Eisenman, Bell [42] }\end{array}$ & Electronic prescribing & Five primary care practices in the US. & $\begin{array}{l}\text { Multiple Case } \\
\text { Study }\end{array}$ & $\begin{array}{l}\text { Identify the factors associated with } \\
\text { implementation of electronic } \\
\text { prescribing. }\end{array}$ \\
\hline
\end{tabular}

Summary findings

Study emphasized the importance of having a product champion for the adoption of a telemedicine initiative in New Zealand.

Study emphasized the importance of having a product champion for the adoption of a telemedicine initiative in New Zealand.

Lack of knowledge about the formal project aims, training and communication with organizational leaders were barriers to implementation.

Three types of "special people" have been identified as key personnel in the implementation of CPOE.

Four themes: organizational issues (e.g., collaboration); clinical/professional issues; technical//T implementation issues; organization of information

Joint selection and purchase, and implementation of EHRs with CDS; centrally managed EHR, and improved data are necessary.

Workflow integration, well designed user interfaces, knowledge management, and intentional interaction among stakeholders are key factors in CDS implementation.

Extra resources, such as manpower, and committed leadership are key factors in implementation.

Strong physician leadership is a key element for the implementation of an HIT screening intervention.

Face-to-face contact with practice staff, and a designated champion were keys to implementation of pharmacy HIT.

Implementation of electronic prescribing requires workflow redesign, and improved health information exchange. 
Table 1 Summary of articles included in the review of HIT champions $(n=42)$ (Continued)

Culler, Jose, Kohler,

Edwards, Dee, Sainfort,

Rask [45]

Feldman, Schooley, Bhavsar [49]

Feldstein, Schneider,

Unitan, Perin, Smith,

Nichols, Lee [58]

Gagnon, Desmartis,

Labrecque, Legare,

Lamothe, Fortin,

Rancourt, Duplantie [36]

\section{Garfield and Watson Telehealth}

[50]

Gordon, Camhi, Hesse

Odlum, Schnall,

Rodriguez, Valdez,

Bakken [25]

Greiver, Barnsley, Glazier, Electronic Medical Records Moineddin, Harvey [37]

Halbesleben, Wakefield, Ward, Brokel, Crandall [51]

Clinical Information System (CIS). Includes an electronic health record (EHR) with computerized physician order entry (CPOE).

Hao, Padman, Telang [26] Mobile Clinical Access Portal (MCAP) with secured wireless PDA-based solution providing access to electronic medical record system (EMR).

Hartswood, Procter, Rouchy, Rouncefiled, Slack, Voss [29] Improved electronic tools for management of patient records and patient care.

Hendy and Barlow [43] Telehealth
Two pediatric hospitals - Egleston Children's Health Care and Scottish Rite Children's Medical Center (UK).

Case study

Describe the facilitators and barriers to the implementation of an inpatient pharmacy system.

Health system in Virginia

Case study

Non-profit group model HMO, Kaiser

Permanente Northwest, in Washington and Oregon (US).

Family medicine group (FMG) in Quebec, Canada.

State telemedicine initiatives in Georgia, Multiple case Pennsylvania, Ohio, and Wisconsin. study

NYPS SelectHealth HIV/AIDS care sites in New York City (USA).

18 community-based family physician practices in Toronto, Canada

Large, Midwestern rural referral hospital. Case study

Community-based healthcare system in southwestern Pennsylvania.

Multivariate regression analysis

Toxicology ward of a large hospital.

Case study

Three health and social care organizations Multiple case

with experience in telehealth in England study (UK). contextual factors associated with

HIT.

Investigate technical, organizational, Project champions play a key decisionand governance of HIE implementation making role in governance

Examine health care workers attitudes toward the adoption and use of a Patient Panel Support tool.

Explore factors that influence the implementation of an EMR.

Examine factors contributing to the success of telemedicine initiatives.

\section{Examine the processes and outcomes} of a Continuity of Care Document/PHR for people living with HIV/AIDS.

Examine factors influencing the implementation of electronic medical records.

Explore the impact of Super Users on the implementation of a CIS.

Examine empirical evidence for the physician adoption of a PDA-based electronic medical record system.

Explore the process of participant design of health information technology.

Examine the role of champions in telehealth initiatives.
Training super-users, extensive premplementation training, formal feed back mechanisms, and technical support following deployment are facilitators of

Implementation required roles for non-PCP staff, leadership, training, and dedicated time for using the HIT.

Organizational factors such as presence of a champion, innovative culture, personal characteristics, and a scientifically based implementation strategy are important.

'Technical' and 'user champions' may be necessary to implement telemedicine interventions.

Training and organizational commitment are important factors in implementation of a PHR.

EMR implementation was also influenced by lack of leadership, relative advantage, available organizational slack.

Super-users, and leadership support for super users are important factors in implementation of (CIS).

Opinion leaders have significant effects on physician adoption of PDA-based EHR systems.

HIT professionals must design and develop systems with users.

Questions the positive and necessary role that champions play in HIT implementation. high complexity, low compatibility, and 
Table 1 Summary of articles included in the review of HIT champions $(n=42)$ (Continued)

\begin{tabular}{lll}
\hline Hsiao, Li, Chen, Ko [23] & $\begin{array}{l}\text { Mobile nursing information } \\
\text { system }\end{array}$ & $\begin{array}{l}\text { Eighty-four Nursing Directors at } \\
\text { Hospitals in Taiwan }\end{array}$ \\
&
\end{tabular}

Leidner, Preston

Chen [28]

Hospital health information technology.

McAlearney, Schweikhart, Handheld computers in Medow [48] clinical practice.

Miller and Sim [46] Electronic medical record (EMR).

Novak, Anders, Gadd, Lorenzi [52]

Paré, Elam, Ward [38]

\section{Barcode medication} administration (BCMA)

Patient charting system (PCS).
Matched pairs of $\mathrm{ClO}$ and executives.

161 informants at seven clinica practice sites.

EMR managers in physician champions in 30 physician organizations.

Multi-hospital, tertiary medical center in the US.

Burn center of a large, not-for-profit teaching hospital.
Multivariate

regression

analysis

Multivariate

regression

analysis

Multiple case study

Multiple case study

Case study

Case study

\section{pxatien \\ Ex}

Examine the factors associated with doption of MNIS

Examine the hospital characteristics associated with IT innovation.

Describe strategies that promote use f handheld computers.

Identify key barriers to physician's use of EMRs.

Examine mediators efforts to implement BCMA

Examine the implementation of a patient charting system.

Identifying the risks associated with the implementation of CIS.

Participants with backgrounds in CIS Delphi study project management.

Girouard [41]$$
\text { (CIS). }
$$

Paré, Sicotte, Poba-Nzaou, Mobile computing

Balouzakis [61] technology; Clinical

information system (CIS).

Piscotty, Tzeng [59]

Clinical information system (CIS)

Electronic health records (EHR)

Pronovost [55]

Postema, Peeters,

Telehealth

Friele [44]
Future users of mobile computing

and a large teaching hospital

implementation of CIS.

Regional multi-hospital system.

Clinical units at an academic medical center $(n=9)$.

Care organizations in the Netherlands $(n=3)$ study

Structured program evaluation study
Examine clinicians' early perceptions of organizational readiness for change with clinical information system projects.

Multiple case adopted by chief nurse executives.

Multiple case
Evaluate the effectiveness of peer coaches impact on increasing learner satisfaction and confidence in EHR use.

Examine the key factors that improve implementation of
Organizations should scan environment, identify mobile nursing needs, and develop vendor relationships in order to adopt.

There are different types of ClO-Board dynamics that affect the role of $\mathrm{ClO}$ as a champion and his/her champion behaviors.

Organizations will use different strategies that promote handheld computer use and remain responsive to physician needs.

Practices without physician champions are likely to struggle to achieve quality or financial benefits.

Clinicians can improve the safety and effectiveness of BCMA implementation with institutional support.

Patient charting system implementation requires key actors anticipating and proactive with challenges; key actors are associated with quality of implementation; PCS implementation is indeterminate process, and outcomes are associated with management of the process and actions after introduction of system.

Risk management is a key strategy throughout the implementation of CIS.

Organizational readiness for change is a key factor in clinician's initial support for implementation of CIS.

Chief nurse executives suggested that champions are necessary at multiple organizational levels to obtain buy in and gather support for implementation.

Peer coaches had a positive effect on satisfaction and confidence.

Technical stability and the alignment of the external environment with organizational goals and implementation strategy are key factors. 
Table 1 Summary of articles included in the review of HIT champions ( $n=42)$ (Continued)

Shachak, Montgomery Electronic medical records

Dow, Barnsley, Tu, Jadad, (EMR)

Lemieux-Charles [74]

Sharkey, Hudak, Horn, Barrett, Spector,

Shaw, Howard, West, Crabtree, Nease, Tutt,

Nutting [39]

Sloane, Wroth, Halladay, Quality monitoring and Bray, Spragens, Stearns, reporting initiative.

Zimmerman [40]

Verhoeven, Steehouder, Website with infection Hendrix, van Gemert- control guidelines. Pijnen [27]

Wright, Ash, Erickson Wasserman, Bunce, Stanescu, St Hilaire,

Panzenhagen, Gebhardt,

McMullen, Sittig [53]

Yuan, Bradley,

Nembhard [30]

Yusof [64]

Electronic health records (EHR)

Critical care information system

Zandieh, Yoon-Flannery, Electronic health records Kuperman, Langsam, (EHR)

Clinical decision support ools for pressure ulcer prevention.

Clinical decision support (CDS)
Limcangco [60]

Four family health teams, one family

health organization (Canada).

\section{study}

Hyman, Kaushal [62]
Nursing homes in Washington, D.C. (USA) $(n=14)$.

Primary care practices in Colorado (USA) $(n=14)$

Primary care practices in North Carolina (USA)

Health care workers at 5 occupational groups in 4 hospitals in the Netherlands study and Germany $(n=20)$

Two community hospitals; an academic Multiple case medical center and outpatient clinic;

Veterans Administration hospital

outpatient clinics; community

outpatient independent physician

association; and academic outpatient clinic.

Two medical units of a large academic hospital

Intensive care unit of tertiary referral center (Malayasia)

Case study

Practice managers $(n=11)$ and medical Case study directors $(n=12)$ from ambulatory care

network of large teaching hospital

New York City (USA).
Multiple case

Mixed methods Investigate behaviors of EHR case study super-users.

Investigate user expectations and needs for end-user support for EMR.

Multivariate regression

Examine nursing home factors associated with implementation of clinical decision support tools for pressure ulcer prevention.

Multiple case

What are the roles of champions in the implementation of organizational innovations.

Multiple case Examine the factors that impact initiation and maintenance of a quality monitoring and reporting process.

Identify factors impacting health care workers use of a website for communicating infection contro guidelines.

Examine activities in the implementation of CDS. adoption of a critical care information system

Examine the different approaches to EHR implementation between

organizations from paper-based vs. legacy EHRs.
Highlights importance of on-site support and super-users in liaison roles, local development of support practices, and gaps in understanding of other organizational members' work processes.

High involvement of nurse managers, in-house dietitian, high participation from staff educator and QI personnel, internal champions, and openness to redesign were associated with implementation.

Two types of champions are key specific project champions, and organizational change champions.

Complex sets of factors are required to mplement and sustain quality-reporting interventions.

Organizational factors play the key role in implementation, and inclusion of the health care workers is essential in the design process

Implementation of CDS requires a variety of skills and activities.

Super-users may support or hinder implementation.

Champions may be important, but other organizational factors may promote or hinder implement

Physician information technology champions was a priority for organizations with paper-based records implementing EHRs, but not a priority for those moving from a legacy EHR to a more sophisticated EHR. 
Table 2 Summary of champion characteristics, influence tactics, and impacts

\begin{tabular}{|c|c|c|c|c|c|c|c|c|}
\hline Reference & Champion type & Role in organization & $\begin{array}{l}\text { IT experience } \\
\text { or training }\end{array}$ & $\begin{array}{l}\text { Champion was } \\
\text { formal or emergent }\end{array}$ & Personality of champion & Tactics used by champion & $\begin{array}{l}\text { Management } \\
\text { support }\end{array}$ & $\begin{array}{l}\text { Impact of } \\
\text { champion }\end{array}$ \\
\hline Al-qirim [32] & Clinical & Dermatologist & NA & Emergent & Achievement, innovative & NA & NA & Positive \\
\hline Al-qirim [32] & $\begin{array}{l}\text { Hybrid } \\
\text { (clinical/admin) }\end{array}$ & Head of Dermatology & NA & Emergent & NA & Building coalitions & NA & NA \\
\hline Al-qirim [33] & Admin & General Manager & NA & Emergent & Achievement, innovative & $\begin{array}{l}\text { Appeal to higher authority, rational } \\
\text { arguments }\end{array}$ & NA & NA \\
\hline Al-qirim [33] & Clinical & Dermatologist & NA & Emergent & Achievement, innovative & NA & NA & Positive \\
\hline Al-qirim [33] & $\begin{array}{l}\text { Hybrid } \\
\text { (clinical/admin) }\end{array}$ & Head of Dermatology & NA & Emergent & NA & $\begin{array}{l}\text { Building coalitions, rational } \\
\text { arguments }\end{array}$ & NA & NA \\
\hline Ash et al. [34] & Varies & $\begin{array}{l}\text { High-level leaders, } \\
\text { non-clinicians, clinicians }\end{array}$ & Varies & NA & $\begin{array}{l}\text { Achievement, innovative, } \\
\text { persistence, persuasive }\end{array}$ & $\begin{array}{l}\text { Building coalitions, rational } \\
\text { arguments }\end{array}$ & Key factor & Positive \\
\hline Ash et al. [57] & Clinical & Clinical champion & NA & Formal & NA & NA & NA & NA \\
\hline Ash et al. [47] & Clinical & Non- clinicians, clinicians & Varies & NA & Charismatic, Innovative & $\begin{array}{l}\text { Building coalitions, rational } \\
\text { arguments }\end{array}$ & Yes & Positive \\
\hline $\begin{array}{l}\text { Carlfjord et al. } \\
{[35]}\end{array}$ & NA & NA & NA & NA & Achievement, innovative & NA & Key factor & NA \\
\hline $\begin{array}{l}\text { Chedid et al. } \\
\text { [56] }\end{array}$ & Clinical & Physician & NA & NA & NA & NA & NA & NA \\
\hline $\begin{array}{l}\text { Cresswell et al. } \\
\text { [24] }\end{array}$ & $\begin{array}{l}\text { Hybrid } \\
\text { (clinical/admin) }\end{array}$ & Pharmacists & NA & Formal & NA & Individualized consideration & Key factor & Positive \\
\hline $\begin{array}{l}\text { Cresswell et al. } \\
{[24]}\end{array}$ & Admin & Practice managers & NA & NA & NA & Individualized consideration & NA & Positive \\
\hline $\begin{array}{l}\text { Crosson et al. } \\
\text { [42] }\end{array}$ & $\begin{array}{l}\text { Varied } \\
\text { (clinical/admin) }\end{array}$ & Physician & Yes & Formal & Innovative, persuasive & Charisma & NA & Positive \\
\hline $\begin{array}{l}\text { Culler et al. } \\
\text { [45] }\end{array}$ & Clinical & Pharmacists & Yes & Formal & Persistence & Rational arguments & NA & Positive \\
\hline $\begin{array}{l}\text { Feldman et al. } \\
\text { [49] }\end{array}$ & $\begin{array}{l}\text { Hybrid } \\
\text { (admin/technical) }\end{array}$ & $\begin{array}{l}\text { Executive Vice President, } \\
\text { Chief Technology Officer }\end{array}$ & NA & Formal & NA & $\begin{array}{l}\text { Assertive actions, rational } \\
\text { arguments }\end{array}$ & Key factor & NA \\
\hline $\begin{array}{l}\text { Feldstein et al. } \\
\text { [58] }\end{array}$ & Varies & Staff & Yes & Formal & NA & NA & Key factor & NA \\
\hline $\begin{array}{l}\text { Gagnon et al. } \\
\text { [36] }\end{array}$ & $\begin{array}{l}\text { Hybrid } \\
\text { (clinical/technical) }\end{array}$ & Physician & Yes & Formal & $\begin{array}{l}\text { Achievement, innovative, } \\
\text { persistence, persuasive }\end{array}$ & $\begin{array}{l}\text { Assertive actions, building coalitions, } \\
\text { Individual consideration, Ingratiation }\end{array}$ & NA & Positive \\
\hline $\begin{array}{l}\text { Garfield and } \\
\text { Watson [50] }\end{array}$ & Technical & $\begin{array}{l}\text { Telemedicine } \\
\text { Coordinator }\end{array}$ & Yes & Formal & NA & NA & NA & Positive \\
\hline $\begin{array}{l}\text { Garfield and } \\
\text { Watson [50] }\end{array}$ & Admin & President of MCG & NA & NA & NA & NA & NA & Positive \\
\hline $\begin{array}{l}\text { Greiver et al. } \\
\text { [37] }\end{array}$ & NA & NA & NA & NA & Achievement, persuasive & NA & No & Positive \\
\hline
\end{tabular}


Table 2 Summary of champion characteristics, influence tactics, and impacts (Continued)

\begin{tabular}{|c|c|c|c|c|c|c|c|c|}
\hline $\begin{array}{l}\text { Halbesleben } \\
\text { et al. [51] }\end{array}$ & $\begin{array}{l}\text { Hybrid } \\
\text { (clinical/admin) }\end{array}$ & Nurses, Nurse Managers & Yes & Formal & NA & NA & NA & Positive \\
\hline Hao et al. [26] & Clinical & Physician & Yes & Informal & NA & NA & NA & Positive \\
\hline $\begin{array}{l}\text { Hartswood } \\
\text { et al. [29] }\end{array}$ & Tech & IT staff & Yes & Formal & Persistence, persuasive & Bargaining & NA & NA \\
\hline $\begin{array}{l}\text { Hendy and } \\
\text { Barlow [43] }\end{array}$ & NA & $\begin{array}{l}\text { Telehealth Project } \\
\text { Manager }\end{array}$ & Yes & NA & $\begin{array}{l}\text { Achievement, innovative, } \\
\text { persistence, persuasive }\end{array}$ & $\begin{array}{l}\text { Building coalitions, intellectual } \\
\text { stimulation, clandestine actions }\end{array}$ & NA & Varied \\
\hline $\begin{array}{l}\text { Hendy and } \\
\text { Barlow [43] }\end{array}$ & NA & Project Manager & Yes & NA & Persistence, persuasive & Bargaining & NA & Varied \\
\hline $\begin{array}{l}\text { Leidner et al. } \\
\text { [28] }\end{array}$ & Hybrid & $\mathrm{ClO}$ & Yes & Formal & Achievement, innovative & Assertive actions, Building coalitions & Varied & Varied \\
\hline $\begin{array}{l}\text { Leidner et al. } \\
\text { [28] }\end{array}$ & Hybrid & $\mathrm{ClO}$ & Yes & Formal & Achievement, innovative & Rational arguments, bargaining & Varied & Varied \\
\hline $\begin{array}{l}\text { Leidner et al. } \\
\text { [28] }\end{array}$ & Hybrid & $\mathrm{ClO}$ & Yes & Formal & Innovative & Rational arguments, bargaining & Varied & Varied \\
\hline $\begin{array}{l}\text { Leidner et al. } \\
\text { [28] }\end{array}$ & Hybrid & $\mathrm{ClO}$ & Yes & Formal & Innovative & Assertive actions & Varied & Varied \\
\hline $\begin{array}{l}\text { McAlearney } \\
\text { et al. [48] }\end{array}$ & Clinical & Physician & Yes & NA & Innovative & Building coalitions & NA & Positive \\
\hline $\begin{array}{l}\text { Miller and Sim } \\
{[46]}\end{array}$ & $\begin{array}{l}\text { Hybrid } \\
\text { (clinical/technical) }\end{array}$ & Physician & Yes & NA & Innovative, persistent & Assertive actions & NA & Positive \\
\hline $\begin{array}{l}\text { Novak et al. } \\
\text { [52] }\end{array}$ & Admin & Nursing Executive & NA & Informal & NA & $\begin{array}{l}\text { Applying sanctions, friendliness and } \\
\text { ingratiation }\end{array}$ & Yes & NA \\
\hline Paré et al. [38] & $\begin{array}{l}\text { Hybrid } \\
\text { (clin/admin) }\end{array}$ & Nurse Managers & NA & Informal & $\begin{array}{l}\text { Achievement, innovative, } \\
\text { persistence, persuasive }\end{array}$ & Rational arguments & NA & Positive \\
\hline Paré et al. [38] & $\begin{array}{l}\text { Hybrid } \\
\text { (clin/admin) }\end{array}$ & Medical Director & NA & Informal & $\begin{array}{l}\text { Achievement, innovative, risk- } \\
\text { taking, persuasive, persistence }\end{array}$ & $\begin{array}{l}\text { Building coalitions, higher authority, } \\
\text { sanctions, bargaining, assertive }\end{array}$ & NA & Positive \\
\hline Paré et al. [41] & Clinical & $\begin{array}{l}\text { Physician - medical } \\
\text { director }\end{array}$ & NA & NA & Persistence, persuasive & NA & Key factor & NA \\
\hline Paré et al. [61] & & Nurses and Physicians & NA & NA & NA & NA & Yes & Varied \\
\hline $\begin{array}{l}\text { Piscotty and } \\
\text { Tzeng [59] }\end{array}$ & Clinical & Nurse & Varies & NA & NA & Building coalitions & NA & NA \\
\hline Poe et al. [55] & Clinical & Nurse - peer coach & Yes & Formal & NA & Ingratiation & NA & Positive \\
\hline $\begin{array}{l}\text { Postema et al. } \\
{[44]}\end{array}$ & $\begin{array}{l}\text { Hybrid } \\
\text { (clinical/admin) }\end{array}$ & $\begin{array}{l}\text { "Enthusiastic } \\
\text { ambassadors" }\end{array}$ & NA & NA & Persistence, persuasive & $\begin{array}{l}\text { Individualized consideration, rational } \\
\text { arguments }\end{array}$ & Yes & Varied \\
\hline $\begin{array}{l}\text { Sharkey et al. } \\
\text { [60] }\end{array}$ & Varied & Nurse/Mids/Admin & NA & NA & NA & NA & Yes & Positive \\
\hline $\begin{array}{l}\text { Shaw et al. } \\
{[39]}\end{array}$ & $\begin{array}{l}\text { Hybrid } \\
\text { (clinical/admin) }\end{array}$ & Lead Physician & NA & Informal & Achievement, innovative & Assertive actions & NA & Positive \\
\hline
\end{tabular}


Table 2 Summary of champion characteristics, influence tactics, and impacts (Continued)

\begin{tabular}{|c|c|c|c|c|c|c|c|c|}
\hline $\begin{array}{l}\text { Shaw et al. } \\
\text { [39] }\end{array}$ & NA & Team members & NA & Informal & NA & NA & NA & Positive \\
\hline $\begin{array}{l}\text { Shaw et al. } \\
\text { [39] }\end{array}$ & Clinical & Physician Assistant & NA & Informal & NA & NA & Yes & $\begin{array}{l}\text { Implementation } \\
\text { failed }\end{array}$ \\
\hline $\begin{array}{l}\text { Shaw et al. } \\
{[39]}\end{array}$ & NA & Various & NA & NA & NA & NA & NA & $\begin{array}{l}\text { Implementation } \\
\text { failed }\end{array}$ \\
\hline $\begin{array}{l}\text { Shaw et al. } \\
\text { [39] }\end{array}$ & $\begin{array}{l}\text { Hybrid } \\
\text { (clinical/admin) }\end{array}$ & Med Director & NA & Formal & NA & NA & NA & $\begin{array}{l}\text { Implementation } \\
\text { failed }\end{array}$ \\
\hline $\begin{array}{l}\text { Shaw et al. } \\
\text { [39] }\end{array}$ & Admin & Office Manager & NA & Formal & NA & NA & NA & $\begin{array}{l}\text { Implementation } \\
\text { failed }\end{array}$ \\
\hline $\begin{array}{l}\text { Shaw et al. } \\
\text { [39] }\end{array}$ & $\begin{array}{l}\text { Hybrid } \\
\text { (clinical/admin) }\end{array}$ & Med Director & NA & Informal & Achievement, innovative & Building coalitions & Yes & Positive \\
\hline $\begin{array}{l}\text { Shaw et al. } \\
\text { [39] }\end{array}$ & Clinical & Nurse & NA & Formal & NA & NA & Yes & Positive \\
\hline $\begin{array}{l}\text { Shaw et al. } \\
\text { [39] }\end{array}$ & Clinical & Physician Assistant & NA & Formal & Achievement, innovative & Building coalitions & NA & NA \\
\hline $\begin{array}{l}\text { Shaw et al. } \\
{[39]}\end{array}$ & Clinical & Physician & NA & Formal & NA & NA & NA & NA \\
\hline $\begin{array}{l}\text { Shaw et al. } \\
\text { [39] }\end{array}$ & $\begin{array}{l}\text { Hybrid } \\
\text { (clinical/admin) }\end{array}$ & Physician & NA & Informal & $\begin{array}{l}\text { Achievement, innovative, } \\
\text { persistence, persuasive }\end{array}$ & Building coalitions & NA & Positive \\
\hline $\begin{array}{l}\text { Sloan et al. } \\
{[40]}\end{array}$ & $\begin{array}{l}\text { Hybrid } \\
\text { (clinical/admin) }\end{array}$ & Physician & Varies & NA & Achievement, innovative & Rational arguments & Yes & Positive \\
\hline $\begin{array}{l}\text { Verhoeven } \\
\text { et al. [27] }\end{array}$ & Clinical & Nurses & NA & NA & NA & Rational arguments & Yes & Positive \\
\hline $\begin{array}{l}\text { Wright et al. } \\
\text { [54] }\end{array}$ & Admin & Multiple (various) & Yes & NA & NA & NA & Yes & NA \\
\hline $\begin{array}{l}\text { Yuan et al. } \\
\text { [30] }\end{array}$ & NA & Multiple (various) & NA & NA & NA & $\begin{array}{l}\text { Assertive actions, individualized } \\
\text { consideration }\end{array}$ & Yes & $\begin{array}{l}\text { Positive and } \\
\text { negative }\end{array}$ \\
\hline Yusof [64] & Clinical & Multiple (various) & NA & Yes & NA & Building coalitions & No & Positive \\
\hline $\begin{array}{l}\text { Zandieh et al. } \\
\text { [62] }\end{array}$ & Clinical & Physician & NA & NA & NA & NA & Yes & Positive \\
\hline
\end{tabular}


champions were formally appointed $[24,28-30,32,36,39$, $42,45,50,51,55,57,58]$. The study by Yuan and colleagues, which included both emergent and appointed champions, identified this difference as a key contextual factor influencing the champion's approach [30].

\section{Experience and training}

Experience and/or training may be influenced by the organizational role of the champion (e.g., clinicians must have clinical training). Over half of the champions in our study were physicians; however, other studies identified pharmacists, physician's assistants [24, 39, 46], and nursing staff $[27,30,38,39,51,52,55,59,60]$. Finally, some studies described champions without clinical training $[29,33,39,54]$. Some champions had both clinical and technical experience or training, such as technologically savvy physicians $[28,29,36,42,45,46,48,51,54,55]$. Several studies described champions with various levels of experience and training with information technology [40, 47, 59]; however, the majority of studies did not identify whether champions had specific experience or training with information technology $[24,27,32,33,35$, $37-39,41,44,50,52,56,57,60-62]$.

\section{Types of champions}

Our findings related to personality characteristics, organizational role, and experience and training suggest different categories of HIT champions: clinical, technological, administrative, and hybrid. Clinical champions have clinical training, perform clinical activities within the organization, and interact with other clinical users of the innovation. Technological champions have ITspecific expertise and are able to maintain the technological infrastructure of the innovation and/or provide technical assistance to users of the innovation. Administrative champions are found within various levels of the organization-senior leadership (e.g., CIO); midlevel management (e.g., department manager); and frontline staff (e.g., nurse). These champions may perform such functions as strategy development, program administration, or project coordination. Hybrid champions are individuals who illustrate two or more of the aforementioned champion categories. These individuals typically hold dual roles within the organization and/or have multidisciplinary training or experience. This concept of a hybrid champion is similar to the "special people" in Ash and colleagues' study [31]. Such individuals are able to communicate effectively with clinical, IT, and administrative personnel. For example, a hybrid champion may train peers to use the HIT effectively, work with IT staff to customize the HIT, and work with administrators to overcome barriers to the implementation (e.g., policy/bureaucratic barriers, lack of buy-in from senior leadership, frontline staff resistance). Recognizing that there are different types of champions is important for assessing champion characteristics, tactics, and impact because organizational members' expectations of champions may vary Andre et al. [63], as might the champions' goals, depending on the champion type.

\section{Champion influence tactics}

Several studies report various influence tactics used by champions that are similar to those identified by Howell and Higgins [11]: building coalitions [28, 31-33, 36, 38, 39, $43,47-49,57,59]$, appealing to higher authority [33, 38], bargaining $[28,29,38]$, performing clandestine actions [43], presenting rational arguments $[27,28,30,33,36,38$, 40, 42, 44, 47, 64], applying sanctions [38, 52], using friendliness and ingratiation [36, 38, 52], assertive actions [28, 36, 39], individualized consideration [24, 30, 36, 44]; and intellectually stimulating other organizational members [43]. Champions also spent extensive time engaging in workflow redesign $[28,46]$ and overcoming technical challenges [28, 30, 33, 36, 64]. Some champions used multiple combinations of influence tactics such as appealing to higher authority and rational arguments [31, 33, 47]; building coalitions, rational arguments, ingratiation and friendliness [36]; building coalitions and clandestine actions [43]; making rational arguments and bargaining [28]; and applying sanctions, ingratiation and friendliness [52]. In Paré and colleagues' study of the implementation of a patient charting system in the burn center of a large, nonprofit teaching hospital, a champion built coalitions, appealed to higher authority, applied sanctions, bargained, and performed assertive actions [38]. Another study suggests that $\mathrm{CIO}$ champions may employ various tactics, depending on the level of technology knowledge held by the hospital board [28]. Furthermore, when HIT implementation involves multiple organizations (e.g., a health information organization and a health care delivery system), having a champion that spans the organizational boundaries could be a driver of project success, as the champion brings an understanding of the vision and capacity of both organizations [49]. Finally, Yuan and colleagues' study classifies some champion behaviors as supportive of implementation (e.g., reporting problems to someone in a position to fix it and employing teaching strategies that promoted "learning by doing") and other behaviors as causing implementation challenges (e.g., losing patience with coworkers and creating workarounds that undermined appropriate use of the HIT) [30].

\section{Management support for the champion}

Study results suggest that organizations with innovative cultures fostering collaboration and experimentation are supportive of champions during HIT implementation [36]. Specific actions of organizational leaders that illustrate support for champions include being closely involved and affiliated with the new HIT [39, 43, 44, 60, 61], setting 
clear expectations that organizational members use the new HIT [58], supporting pilot projects to allow experimentation with the technology [48], prominently mentioning the new HIT in strategy and policy plans [44], providing access to organizational IT support [60], and recognizing and rewarding champions [43]. Some studies reported insufficient support for the champions' efforts, including perceived lack of system-level leadership support for implementation activities [37], insufficient organizational slack [37], or purchasing equipment but not financially investing in program activities [50].

Information technology-related knowledge of top leadership appears to play a key role in the support provided to champions. For example, Leidner et al. focused on the extent to which a governing board's IT-knowledge influences CIO-level innovation champions in hospitals [28]. They found four types of CIO innovators: board-informing, board-constrained, boardinvisible, and board-driven. Board-informing $\mathrm{CIO}$ innovators work to educate their board on the strategic implications of potential IT solutions. The support CIOs receive appears to be influenced by the extent to which those implications are valued. The board-constrained CIO innovator works with a board that is relatively IT-savvy and comfortable assessing IT opportunities for themselves. These CIOs generally follow the discretion of the board and receive little support for innovation. Boardinvisible CIO innovators operate generally independently of the board, which is not particularly IT-savvy. These CIOs can be well supported for innovation if they develop the trust of their board. Finally, board-driven CIO innovators work with IT-savvy boards that are eager to innovate. CIOs in this environment are well supported in efforts to innovate; however, they may face challenges related to reigning in the board's expectations for IT. In summary, organizational culture and support from leadership and top management appear to be key contextual conditions that affect the priorities, actions, and impact of champions on implementation.

\section{Champion impact}

Our review revealed that studies have assessed three general types of HIT champion impacts: (1) impact on the implementation process of a specific HIT innovation [39, 43, 55]; (2) impact on usage behavior or overall success of a specific HIT innovation [26, 27, 32, 33, 36, $38,39,43,44,49,51,55,59,60,64]$; and (3) impact on general organizational-level innovativeness $[28,39]$. The main thrust of the third type of impact is that a champion's success or failure can have implications beyond the scope of the particular implementation for which they champion. In other words, a champion not only can positively or negatively affect the process and outcome of a particular HIT implementation, but they also can affect the organization's overall experience and capacity related to innovation.

Both quantitative and qualitative approaches have been used to assess impact; however, we found qualitative approaches to be much more commonly used. Only a handful of studies used quantitative methods to assess relationships between the presence of a champion and impacts [26, 51, 60]. Regardless of the methodological approach, most studies reported that the presence of a champion was associated with a positive impact on the implementation process and success of various HIT projects, such as an electronic medical record [36], clinical decision support [47], and e-prescribing [42]. However, some findings indicate that a champion is not necessarily sufficient for successful implementation [27, 43]. Furthermore, some champions may have a greater impact than others. In an analysis of two implementation settings, one of which had a more successful implementation than the other, Yuan and colleagues found variation in champion impact with respect to supporting their peers (proactively versus reactively); depth of explanation (emphasizing why actions had to be performed versus demonstrating how to accomplish tasks but not explaining the logic behind these actions); framing (using positive frames to diffuse tension versus using neutral frames); and information-sharing (consistently sharing information about the HIT with all users versus limiting the spread of information to individuals they interacted with the most) [30].

Some studies suggest that multiple champions may be necessary for a positive impact on implementation. For example, in Parés detailed study of the implementation of a patient charting system, the medical director of the burn center played key roles in adoption and implementation. He exhibited many of the personality characteristics we examined, and used several tactics including building coalitions, appealing to higher authority, bargaining, applying sanctions, and assertive actions. However, nurse managers with characteristics such as innovativeness, persuasiveness, and persistence were also important champions in implementation through the presentation of rational arguments to clinical staff [38]. Furthermore, Shaw and colleagues' multiple-case-study provides examples of eight primary care organizations with no champion; a project champion or an organizational change champion; or a project champion and an organizational change champion [39]. This multiple-case-study suggests that both project and organizational-change champions may be important for implementing and sustaining quality improvement efforts. Although individual project champions may be sufficient for leading a specific change effort, any gains made in the effort could be jeopardized if the effort does not align with the organization's broader plan 
and future vision for change, thus necessitating a highlevel administrative champion.

\section{Comparison of quantitative and qualitative study results}

The quantitative studies in our review focused on the impact of the champion in relation to an organization's readiness for IT implementation, an organization's overall innovativeness in the area of IT, and the adoption of a specific technology by organizational members. In terms of organizational readiness, results from Paré et al. [61] were mixed regarding whether having a project champion increases readiness for an IT-driven change. The study evaluated two different settings and technologies: a nursing information system in an oncology and palliative care unit and an EHR implementation in a large teaching hospital. Having a project champion was not a significant contributor to organizational readiness for the nursing system but was significant for the EHR (path coefficient = $0.23, p<0.05)$. Regarding adoption and implementation of specific technologies, results from Hao et al. [26] show that an individual in a group with an opinion leader (i.e., an individual identified by the health system as an early adopter of the technology) is more likely to adopt handheld device in practice than a user who has no opinion leader in his or her group (odds ratio $=3.125, p<0.05$ ). Similarly, Sharkey et al. [60] found that the presence of a champion was correlated with higher level of implementation of tools for clinical decision support in nursing homes, that is, having a collaborative approach, being highly engaged in ways that CDS report data are used, and implementing three or more process improvements facility-wide (Spearman correlation coefficient $=0.75, p<$ 0.01 ). Regarding impact on overall innovativeness related to IT, results from Leidner et al. [28] suggest that CIO champions demonstrating strategic leadership-that is, whether other executives perceive the CIO to be visionary and able to weave business and IT strategies togetherinfluences whether the hospital is perceived as a leader in HIT.

In general, both the quantitative and qualitative studies in our review yielded somewhat mixed results regarding the impact of champions on HIT implementation; however, positive impacts are more commonly reported in both types of studies. Notably, as compared to the quantitative results, qualitative studies in our review provided more detail about the characteristics, tactics, and management support of the champions being studied and, therefore, are better able to elucidate how a champion contributed to a particular implementation outcome, for example, through face-to-face communication about the value of the technology [24, 34]. These studies provide a basis for developing hypotheses to test in larger studies analyzing determinants of successful HIT implementation using quantitative measures.

\section{Discussion}

The number of empirical studies focusing on HIT champions is relatively modest, and existing studies employ a variety of methodological and measurement approaches. Therefore, identifying evidenced-based practices for HIT champions remains a goal for future research, particularly in light of the complex role of champions in implementation. Nevertheless, our review revealed some important insights.

In general, champions appear to contribute to the successful implementation of many HIT projects. However the extent to which HIT projects fail even with a champion and why such failures occur is less clear. Also unclear is whether all organizations require a champion for successful HIT project implementation. More specifically, we currently do not know enough about the conditions under which (1) a health IT champion is needed, (2) multiple champions are needed, and (3) an appointed champion-as opposed to an emergent champion-can be successful. A number of qualitative studies in our review provide rich details suggesting that organizational climate, resources, technical capability, workflow modifications, and resistance to change influence the characteristics, tactics, management support, and impacts of champions. However, many of our studies provided little detail about characteristics of the organizations or the organizational members undergoing implementation, let alone the circumstances under which the implementation was occurring. Therefore, the extent to which the organizational context may influence the need for a champion (including the number and type of champions); the phase of the IT project that requires a champion (e.g., adoption-decision, pre-implementation planning, etc.); the tactics a champion should employ; and how management can best support the champion(s) remain largely unknown. For example, an organization already undertaking multiple implementation efforts may require a top-level administrator to communicate the strategic value of a new HIT change, including how the effort aligns with broader organizational priorities and change efforts. The organization may also need a team of champions representing various roles to serve as subject matter experts and to assist with training peers to use the system effectively. Multiple-case-study approaches, similar to that used in Shaw et. al., could be useful for assessing relationships between organizational context and champion characteristics, tactics, and impacts [39].

Robust studies that focus on champions and HIT implementation effectiveness, require appropriate theories to guide hypothesis generation. The model we employed to guide our review was useful for characterizing the nature of the literature; however, we believe it would require modification in order to inform future research on HIT champions. In general, more attention is needed 
to developing theory that predicts champion impacts given the number and characteristics of champions, tactics they employ, characteristics of the HIT being implemented, and organizational context within which the implementation is occurring. Theory development should account for different types and levels of impact (e.g., impacts on user adoption, user productivity, and organizational capacity for future implementations). Without theory-informed studies, our understanding of the conditions under which champions promote successful implementation will be dependent upon the results of a small number of studies that may not account for interactions between some of the most influential organizational, individual, and technological factors.

Although our study focused on HIT, our findings complement studies from the information systems literature that are not specific to health care. Specifically, information systems research has demonstrated that change agents have varying characteristics and roles during implementation [65]; employ various influence tactics [66, 67]; frequently depend on management support, alliances, organizational context $[68,69]$; and are associated with positive and negative implementation outcomes [65]. Also, characteristics, roles, influence tactics, support, organizational context, and outcomes have been found to be associated with the complexity of information system implementation [70, 71]. Finally, studies have suggested that complex adaptive system theory holds promise for future work related to developing HIT implementation frameworks $[72,73]$.

\section{Limitations}

Our review has a few limitations. First, we identified a relatively small number of studies focused on HIT champions. Second, many of these studies did not focus explicitly on HIT champions but rather studied HIT implementation in general and included champions as a part of that analysis or as an emergent finding. Third, studies included in our review varied in terms of their level of detail about champions and their methods (with most studies being qualitative). Given the various ways in which champions have been defined and studied, abstracting data for each study required substantial discussion between the authors and an iterative process. However, we believe having a team comprised of researchers with qualitative data analysis experience enhanced the validity of our findings. Finally, we believe these limitations are not uncommon for a scoping review designed to describe the nature of the literature on a broad research question.

\section{Conclusions}

Our review was carried out to assess the extent and scope of research on HIT champions for the purpose of informing future research. We identified 42 studies pertinent to HIT champions. Our findings suggest that additional research is needed to analyze the characteristics, influence tactics, and management support needed for different categories of champions. Future work should view champions as one component within the organizational infrastructure for HIT implementation. Answers to questions about who champions should be, when they should be engaged, what they should do, how management can support their efforts, and what their impact will be are likely dependent upon other aspects within the organization. Because many organizations currently appoint champions for HIT projects, rather than allowing them to emerge, researchers should focus on developing evidence-based frameworks and/or tools that assist with identifying which aspects of an implementation require such a champion's efforts, the experience and skills the champion needs in order to perform effectively, and the types of management support that the champion will need.

\section{Competing interests \\ The authors declare that they have no competing interests.}

\section{Authors' contributions}

CS conceptualized the manuscript, participated in review of articles, and led the drafting of the manuscript. CB conducted the literature searches, led the data extraction, and contributed to drafting the manuscript. Both authors read and approved the final manuscript.

\section{Acknowledgments}

Dr. Christopher M. Shea was supported by the National Center for Research Resources and the National Center for Advancing Translational Sciences, National Institutes of Health (KL2TR001109) (UL1TR001111). Dr. Shea also received support from the Department of Practice Quality and Innovation at UNC Health Care. The content is solely the responsibility of the authors and does not necessarily represent the official views of the $\mathrm{NIH}$ or UNC Health Care.

Received: 23 September 2015 Accepted: 5 January 2016

Published online: 12 January 2016

References

1. King J, Patel V, Furukawa MF. Physician adoption of electronic health record technology to meet meaningful use objectives: 2009-2012. ONC data brief, no.7. Washington: Office of the National Coordinator for Health Information Technology; 2012.

2. Adler-Milstein J, Furukawa MF, King J, Jha AK. Early results from the hospital electronic health record incentive programs. Am J Manag Care. 2013;19(7):e273-84.

3. Centers for Medicare \& Medicaid Services. Data and Program Reports Centers for Medicare \& Medicaid Services. https://www.cms.gov/ Regulations-and-Guidance/Legislation/EHRIncentivePrograms/Downloads/ July2015_SummaryReport.pdf 2015. Accessed 27 August 2015.

4. Rudin R, Volk L, Simon S, Bates D. What affects clinicians' usage of health information exchange? Applied Clinical Informatics. 2011;2(3):250-62.

5. Walker JM, Carayon P. From tasks to processes: The case for changing health information technology to improve health care. Health Aff. 2009;28(2):467-77.

6. Notte C. Pre-implementation Planning and Workflow Analysis. Skolnik N editor. Electronic Medical Records: A Practical Guide for Primary Care. Totowa, NJ: Humana Press, Inc; 2011.

7. Weiner BJ, Lewis MA, Linnan LA. Using organization theory to understand the determinants of effective implementation of worksite health promotion programs. Health Educ Res. 2009;24:292-305. 
8. Helfrich CD, Weiner BJ, McKinney MM, Minasian L. Determinants of implementation effectiveness: Adapting a framework for complex innovations. Med Care Res Rev. 2007;64(3):279-303.

9. Kanter R. The change masters. 1st ed. New York: Simon \& Schuster, Inc; 1983.

10. Ash JS, Stavri PZ, Kuperman GJ. A consensus statement on considerations for a successful CPOE implementation. J Am Med Inform Assoc. 2003;10(3):229-34.

11. Howell JM, Higgins CA. Champions of technological innovation. Adm Sci Q. 1990;35(2):317-41.

12. Howell JM, Shea CM, Higgins CA. Champions of product innovations: Defining, developing, and validating a measure of champion behavior. J Bus Ventur. 2005;20(5):641-61.

13. Grant MJ, Booth A. A typology of reviews: an analysis of 14 review types and associated methodologies. Health Info Libr J. 2009;26(2):91-108.

14. Brien SE, Lorenzetti DL, Lewis S, Kennedy J, Ghali WA. Overview of a formal scoping review on health system report cards. Implement Sci. 2010. doi:10.1186/1748-5908-5-2

15. Levac D, Colquhoun H, O'Brien K. Scoping studies: advancing the methodology. Implement Sci. 2010;5(1):69.

16. Schon D. Champions for radical new inventions. Harv Bus Rev. 1963;41(2):77-86.

17. Rogers EM. Diffusion of innovations. New York: Free Press; 2003.

18. U.S.C. Title 42. The Public Health and Welfare. http://www.gpo.gov/fdsys/pkg/ USCODE-2010-title42/html/USCODE-2010-title42-chap6A-subchapXXVIII.htm. 2010. Accessed 13 May 2014.

19. Arksey H, O'Malley L. Scoping studies: towards a methodological framework. Int J Soc Res Methodol. 2005;8(1):19-32.

20. Garrard J. Health sciences literature review made easy: the matrix method. Sudbury: Jones and Bartlett Publishers; 2007.

21. Siloaho M, Hukkanen K, Kinnunen J. Key elements of the implementation of a quality system in three Finnish clinical laboratories. Clin Chem Lab Med. 2001;39(10):988-96.

22. Loeppke R, Howell JW. Integrating clinical performance improvement across physician organizations: The PhyCor experience. Jt Comm J Qual Improv. 1999:25(2):55-67.

23. Hsiao S, Li Y, Chen Y, Ko H. Critical factors for the adoption of mobile nursing information systems in taiwan: The nursing department administrators' perspective. J Med Syst. 2009;33(5):369-77.

24. Cresswell KM, Sadler S, Rodgers S, Avery A, Cantrill J, Murray SA, et al. An embedded longitudinal multi-faceted qualitative evaluation of a complex cluster randomized controlled trial aiming to reduce clinically important errors in medicines management in general practice. Trials. 2012;13:78.

25. Gordon P, Camhi E, Hesse R, Odlum M, Schnall R, Rodriguez M, et al. Processes and outcomes of developing a continuity of care document for use as a personal health record by people living with HIV/AIDS in new york city. Int J Med Inf. 2012;81(10):e63.

26. Hao H, Padman R, Telang R. An empirical study of opinion leader effects on mobile information technology;adoption in healthcare. AMIA Annu Symp Proc. 2011;2011:537-42.

27. Verhoeven F, Steehouder MF, Hendrix RMG, van Gemert-Pijnen JEWC Factors affecting health care workers' adoption of a website with infection control guidelines. Int J Med Inf. 2009:78(10):663-78.

28. Leidner DE, Preston D, Chen D. An examination of the antecedents and consequences of organizational IT innovation in hospitals. J Strat Inf Syst. 2010;19(3):154-70

29. Hartswood M, Procter R, Rouchy P, Rouncefield M, Slack R, Voss A Working IT out in medical practice: IT systems design and development as co-realisation. Methods Inf Med. 2003;42(4):392-7.

30. Yuan CT, Bradley EH, Nembhard IM. A mixed methods study of how clinician'super users' influence others during the implementation of electronic health records. BMC Med Inform Decis Mak. 2015:15:26. doi:10.1186/s12911-015-0154-6

31. Ash JS, Stavri PZ, Dykstra R, Fournier L. Implementing computerized physician order entry: The importance of special people. Int J Med Inform. 2003:69(2-3):235-50

32. Al-Qirim N. Teledermatology: The case of adoption and diffusion of telemedicine health waikato in New Zealand. Telemedicine J E-Health. 2003;9(2):167-77

33. Al-Qirim N. Championing telemedicine adoption and utilization in healthcare organizations in New Zealand. Int J Med Inf. 2007;76(1):42-54
34. Ash JS, Gorman PN, Lavelle M, Payne TH, Massaro TA, Frantz GL, et al. A cross-site qualitative study of physician order entry. J Am Med Inform Assoc. 2003;10(2):188-200.

35. Carlfjord S, Lindberg M, Andersson A. Staff perceptions of addressing lifestyle in primary health care: A qualitative evaluation 2 years after the introduction of a lifestyle intervention tool. BMC Fam Pract. 2012;13(1):99. doi:10.1186/1471-2296-13-99.

36. Gagnon $M$, Desmartis $M$, Labrecque $M$, Légaré $F$, Lamothe L, Fortin J-P et al. Implementation of an electronic medical record in family practice: A case study. Inform Prim Care. 2010;18:31-40.

37. Greiver M, Barnsley J, Glazier RH, Moineddin R, Harvey BJ. Implementation of electronic medical records theory-informed qualitative study. Can Fam Physician. 2011:57(10):E390-7.

38. Paré G, Elam J, Ward C. Implementation of a patient charting system: Challenges encountered and tactics adopted in a burn center. J Med Syst. 1997;21(1):49-66.

39. Shaw EK, Howard J, West DR, Crabtree BF, Nease Jr DE, Tutt B, et al. The role of the champion in primary care change efforts: From the state networks of colorado ambulatory practices and partners (SNOCAP). J Am Board Fam Med. 2012;25(5):676-85.

40. Sloane PD, Wroth T, Halladay J, Bray P, Spragens L, Stearns S, et al. How eight primary care practices initiated and maintained quality monitoring and reporting. J Am Board Fam Med. 2011;24(4):360-9.

41. Paré G, Sicotte C, Jaana M, Girouard D. Prioritizing clinical information system project risk factors: a delphi study. IEEE. 2008. doi:10.1109/HICSS. 2008.354

42. Crosson JC, Etz RS, Wu S, Straus SG, Eisenman D, Bell DS. Meaningful use of electronic prescribing in 5 exemplar primary care practices. Ann Fam Med. 2011;9(5):392-7.

43. Hendy J, Barlow J. The role of the organizational champion in achieving health system change. Soc Sci Med. 2012;74(3):348-55

44. Postema TRF, Peeters JM, Friele RD. Key factors influencing the implementation success of a home telecare application. Int J Med Inf. 2012;81(6):415-23.

45. Culler SD, Jose J, Kohler S, Edwards P, Dee AD, Sainfort F, et al. Implementing a pharmacy system: facilitators and barriers. J Med Syst. 2009;33(2):81-90.

46. Miller RH, Sim I. Physicians' use of electronic medical records: Barriers and solutions. Health Aff. 2004;23(2):116-26.

47. Ash JS, Bunce A, Middleton B, Sittig DF, Guappone KP, Dykstra RH, et al. Recommended practices for computerized clinical decision support and knowledge management in community settings: a qualitative study. BMC Med Inform Decis Mak. 2012. doi:10.1186/1472-6947-12-6.

48. McAlearney A, Schweikhart S, Medow M. Organizational and physician perspectives about facilitating handheld computer use in clinical practice: results of a cross-site qualitative study. J Am Med Inform Assoc. 2005:12(5):568-75.

49. Feldman SS, Schooley BL, Bhavsar GP. Health information exchange implementation: Lessons learned and critical success factors from a case study. JMIR Med Inform. 2014;2(2):e19.

50. Garfield M, Watson R. Four case studies in state-supported telemedicine initiatives. Telemedicine J E-Health. 2003;9(2):197-205.

51. Halbesleben JRB, Wakefield DS, Ward MM, Brokel J, Crandall D. The relationship between super users' attitudes and employee experiences with clinical information systems. Med Care Res Rev. 2009:66(1):82-96.

52. Novak LL, Anders S, Gadd CS, Lorenzi NM. Mediation of adoption and use: A key strategy for mitigating unintended consequences of health IT implementation. J Am Med Inform Assoc. 2012;19(6):1043-9.

53. Wright A, McMullen C, Middleton B, Sittig DF, Ash JS, Erickson JL, et al. A qualitative study of the activities performed by people involved in clinical decision support: Recommended practices for success. J Am Med Inform Assoc. 2014;21(3):464-72.

54. Wright A, Henkin S, Feblowitz J, McCoy AB, Bates DW, Sittig DF. Early results of the meaningful use program for electronic health records. N Engl J Med. 2013;368(8):779-80.

55. Poe SS, Abbott $P$, Pronovost $P$. Building nursing intellectual capital for safe use of information technology A before-after study to test an evidencebased peer coach intervention. J Nurs Care Qual. 2011:26(2):110-9.

56. Chedid EH, Golden QR, Jager RD. Operational challenges in delivery of a charity care program for diabetic retinopathy screening in an urban setting. Perm J. 2013;17(1):21-5. 
57. Ash JS, Sittig DF, Wright A, McMullen C, Shapiro M, Bunce A, et al. Clinical decision support in small community practice settings: A case study. J Am Med Inform Assoc. 2011;18(6):879-82.

58. Feldstein AC, Schneider JL, Unitan R, Perrin NA, Smith DH, Nichols GA, et al. Health care worker perspectives inform optimization of patient panelsupport tools: A qualitative study. Popul Health Manag. 2013;16(2):107-19.

59. Piscotty RJ, Tzeng H. Exploring the clinical information system implementation readiness activities to support nursing in hospital settings. Cin-Computers Informatics Nursing. 2011;29(11):648-56.

60. Sharkey S, Hudak S, Horn SD, Barrett R, Spector W, Limcangco R. Exploratory study of nursing home factors associated with successful implementation of clinical decision support tools for pressure ulcer prevention. Adv Skin Wound Care. 2013;26(2):83-92.

61. Paré G, Sicotte C, Poba-Nzaou P, Balouzakis G. Clinicians' perceptions of organizational readiness for change in the context of clinical information system projects: Insights from two cross-sectional surveys. Implement Sci. 2011;6:15.

62. Zandieh SO, Yoon-Flannery K, Kuperman GJ, Langsam DJ, Hyman D, Kaushal R. Challenges to EHR implementation in electronic- versus paper-based office practices. J Gen Intern Med. 2008;23(6):755-61.

63. Andre B, Ringdal G, Loge JH, Rannestad T, Kaasa S. The Importance of Key Personnel and Active Management for Successful Implementation of Computer-Based Technology in Palliative Care: Results From a Qualitative Study. Computers, Informatics. Nursing 2008:26(4):183-189.

64. Yusof MM. A case study evaluation of a critical care information system adoption using the socio-technical and fit approach. Int J Med Inf. 2015;84(7):486-99.

65. Markus ML, Benjamin RI. Change agentry: The next IS frontier. MIS Q. 1996;20(4):385-407.

66. Meissonier R, Houze E. Toward an IT conflict-resistance theory: Action research during IT pre-implementation. J Inf Syst. 2010;19(5):450-561.

67. Yuki G, Falbe CM. Influence tactics and objectives in upward, downward, and lateral attempts. J Appl Psychol. 1990;75(2):132-40.

68. Ngwenyama O, Nielsen PA. Using organizational influence processes to overcome IS implementation barriers: Lessons from a longitudinal case study of SPI implementation. Eur J Inf Syst. 2014;23:205-22.

69. Sabherwal R, Jeyaral A, Chowa C. Information systems success: Individual and organizational determinants. Manag Sci. 2006;52(12):1849-64.

70. Botchkarev AFP. Complexity in the context of information system project management. Org Proj Manag. 2015;2(1):15-34.

71. Xia W, Lee G. Grasping the complexity of IS development projects. Commun ACM. 2004;47(5):69-74.

72. Keshavjee K, Kuziemsky C, Vassanji K, Ghany A. A complex adaptive systems perspective of health information technology implementation. Stud Health Technol Inform. 2013;183:209-13.

73. Ellis BHS. Complex adaptive systems (CAS): An overview of key elements, characteristics, and application to management theory. Inform Prim Care. 2011;19:33-7.

74. Shachak A, Barnsley J, Montgomery C, Tu K, Jadad AR, Lemieux-Charles L. End-user support for a primary care electronic medical record: A qualitative case study of a vendor's perspective. Inform Prim Care. 2012;20(3):185-95.

\section{Submit your next manuscript to BioMed Central and we will help you at every step:}

- We accept pre-submission inquiries

- Our selector tool helps you to find the most relevant journal

- We provide round the clock customer support

- Convenient online submission

- Thorough peer review

- Inclusion in PubMed and all major indexing services

- Maximum visibility for your research

Submit your manuscript at www.biomedcentral.com/submit
Biomed Central 